Article

\title{
Density of Dermacentor reticulatus Ticks in Eastern Poland
}

\section{Zbigniew Zając *DiD, Aneta Woźniak and Joanna Kulisz}

Chair and Department of Biology and Parasitology, Medical University of Lublin, 20-080 Lublin, Poland; aneta.wozniak@umlub.pl (A.W.); joanna.kulisz@umlub.pl (J.K.)

* Correspondence: zbigniew.zajac@umlub.pl

Received: 22 March 2020; Accepted: 16 April 2020; Published: 19 April 2020

\begin{abstract}
Dermacentor reticulatus, the ornate cow tick, is second only to Ixodes ricinus as the most important reservoir and vector of infectious diseases in Europe. In recent years, the distribution of D. reticulatus ticks has expanded into new territories, including increased population densities in areas of their previous occurrence. Our investigations around this consisted of two stages. In the first stage, we monitored the seasonal activity of D. reticulatus ticks in Polesie National Park in 2014-2019. The second stage, which was carried out in 2019 at the peak of the spring (March) and autumn (October) activity of this species, included assessment of the density of D. reticulatus ticks in the entire province. To this end, the study area was divided into 101 equal plots that were surveyed for ticks. The seasonal activity of $D$. reticulatus in Polesie National Park showed peaks of activity in autumn in 2014-2018 and in spring in 2019. A total of 19,559 adult D. reticulatus specimens were collected, with a mean of 96.8 specimens $/ 100 \mathrm{~m}^{2}$ in Lublin Province. The area of Lublin Province is characterized by a high density of the ornate cow tick. An increase in the surface area of meadows and fallow land has contributed to a rise in the number of local populations of $D$. reticulatus ticks.
\end{abstract}

Keywords: tick density; Dermacentor reticulatus; tick distribution; tick occurrence

\section{Introduction}

Dermacentor reticulatus, the ornate cow tick, is one of the most widely distributed tick species throughout Europe. As suggested by some authors, two geographically separated populations of ornate cow ticks, known as the "Eastern European" and "Western European", can be distinguished in Europe. This phenomenon is not found in other widely distributed tick species in Europe, such as Ixodes ricinus or D. marginatus [1-3].

In the western part of the continent, the occurrence of $D$. reticulatus has been confirmed in the northern regions of Spain, France, the southern part of the British Isles, Switzerland, Benelux countries, and Germany [3-5]. In Central Europe, numerous localities of this species have been reported in Poland, Hungary, the Slovakian lowlands, Slovenia, and Austria [3,6-9]. In the east, the occurrence range of $D$. reticulatus ticks covers Ukraine, Belarus, Lithuania, Latvia, Estonia, and the European north-west part of Russia. Numerous records have also been reported from the Caucasus and Asia to the Omsk and Novosibirsk regions [2,10-13].

Before the beginning of the 21st century, it was thought that the distribution of $D$. reticulatus in Poland was limited to the territory east of the Vistula River and in the north-eastern part of the country, while western regions were considered non-endemic. Additionally, it was assumed that Poland was the boundary between the eastern and western populations of D. reticulatus [13-15].

Studies on tick ecology and distribution, which have intensified in recent years, have confirmed the occurrence of D. reticulatus in the northern, western, and south-western territories of Poland [16-22]. 
Similar changes in the dynamics and spread of $D$. reticulatus into new areas have also been observed in other European countries, including in Germany, where its recorded distribution before 1970 was limited to western areas, with low numbers reported [23]. In the following years, the distribution of $D$. reticulatus was reported to expand into eastern areas bordering Poland [6]. Many new sites of $D$. reticulatus occurrence have been discovered in the Czech Republic. In Slovakia, new localities of the ornate cow tick, representing both eastern and western European populations, have been reported [24,25]. More recently, D. reticulatus ticks have been reported in Hungary [26-28], where only two sites were documented before the 1970s [9]. Increased abundance and new localities of $D$. reticulatus have also been observed in Romania $[29,30]$. Clustered populations of $D$. reticulatus have been confirmed in the Balkans [31-34] and Iberian Peninsula [35]. The spread of ornate cow ticks to Northern Italy [36], which was previously regarded as tick-free, has been observed recently.

D. reticulatus populations in Europe were previously separated by a geographical border, which is now breaking down due to new introductions. Although genetic studies of specimens of both populations have shown differences in the structure of their genomes [37], the results of these studies do not indicate equivocally the cause of the occurrence of gaps in D. reticulatus distribution in Europe.

The aim of this study was to conduct concurrent large-scale tick surveillance to determine the relative density and distribution of $D$. reticulatus in Lublin Province, Eastern Poland.

\section{Materials and Methods}

The investigations consisted of two stages. In the first stage (2014-2019), we monitored the seasonal activity of $D$. reticulatus ticks in a habitat preferred by the species in Polesie National Park. The results facilitated precise determination of the rhythms of seasonal activity of the species in the spring-autumn period between March and October. The second stage (2019) was focused on assessment of the density of $D$. reticulatus ticks in the entire Lublin Province.

\subsection{Study Area}

\subsubsection{Polesie National Park}

Polesie National Park (51.496 $\left.\mathrm{N}, 23.102^{\circ} \mathrm{E}\right)$ is located in the lowlands of Central-Eastern Poland. The park, covering a surface area of $97.6 \mathrm{~km}^{2}$, is mainly occupied by lakes, ponds, marshes, peat bogs, and meadows [38].

\subsubsection{Lublin Province}

The Province has an area of $25,122 \mathrm{~km}^{2}$, which accounts for $8.02 \%$ of the territory of Poland (Figure 1).

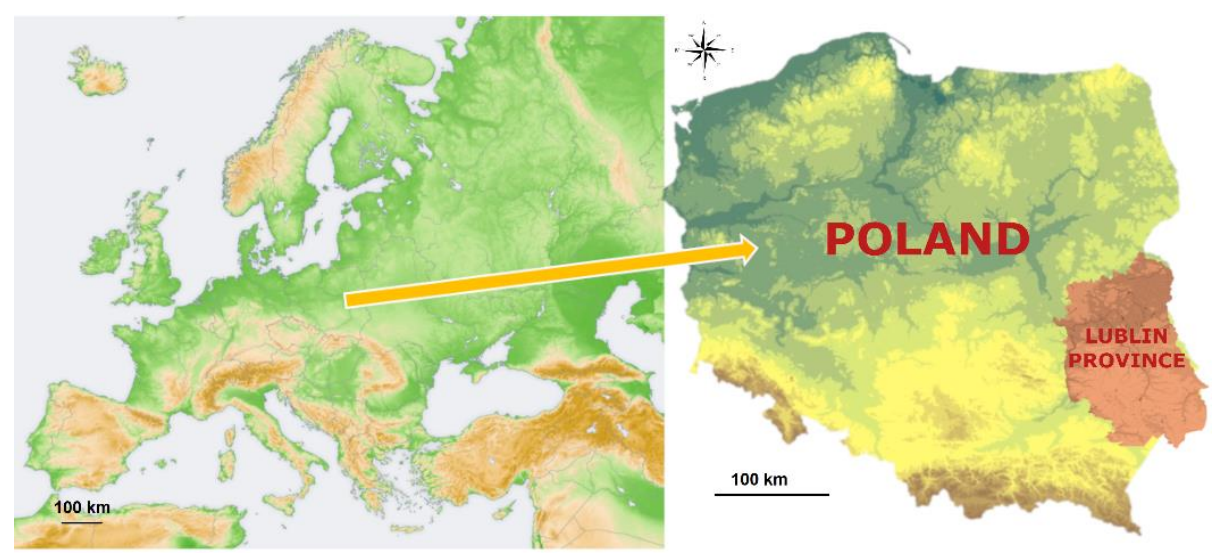

Figure 1. Maps of the study area in Eastern Poland, based on Wikimedia [39,40] with our own modifications. 
Lublin Province is located in an area of four macroregions (Western Polesie, Volyn, South Podlasie Lowland, and Lublin Upland) differing in geomorphological structure, water features, and climate (Figure 2) [41].

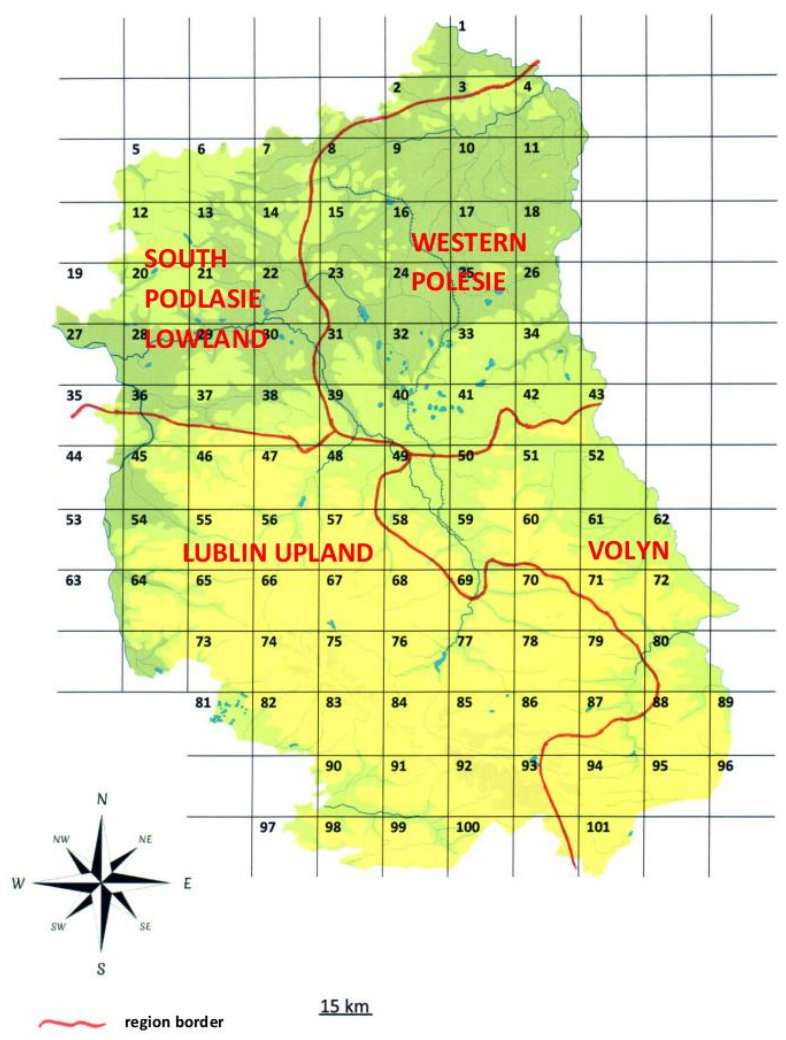

Figure 2. Division of Lublin Province into study plots and physico-geographical regions of Lublin Province, based on Kondracki [41] and Wikimedia [42], with our own modifications.

\subsection{Tick Collection Sites}

\subsubsection{Polesie National Park}

D. reticulatus ticks were collected in a habitat preferred by this species in Polesie National Park [43] (Figure 3).

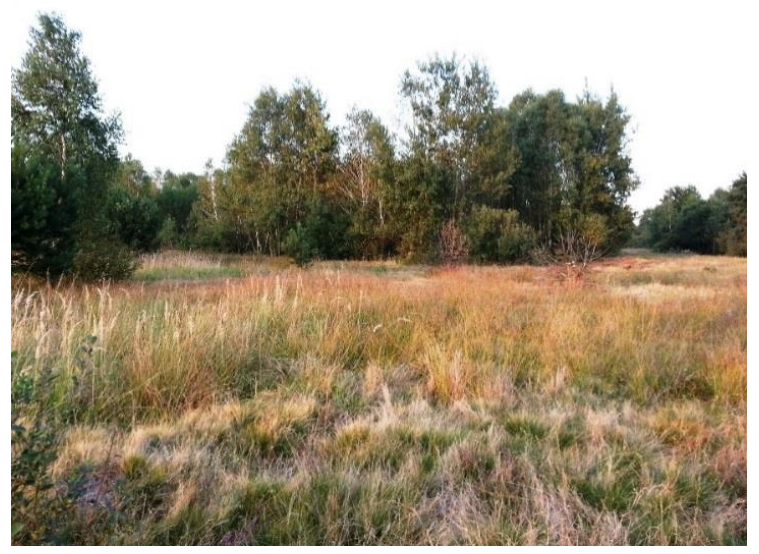

Figure 3. Dermacentor reticulatus collection site in Polesie National Park. 


\subsubsection{Lublin Province}

A grid with sides corresponding to $15.8 \mathrm{~km}$ of terrain was applied to the study site, resulting in 101 squares with a mean area of $250 \mathrm{~km}^{2}$ each, representing $1 \%$ of the landmass of Lublin Province (Figure 2).

Next, satellite photos available in Google Maps were used to establish a potential tick collection site in each square. Grasslands undergoing ecological succession located at the margins of or in close vicinity to forests, and with access to watercourses, were regarded as habitats preferred by these ticks [43]. In each square of the grid, one potential approximately $2500 \mathrm{~m}^{2}$ site of tick collection was established. The next step involved visual inspection of the previously established tick collection sites. In sites that met the assumed criteria, one $100 \mathrm{~m}^{2}$ plot was delineated (Figure 4) for subsequent collection of ticks. In the event of discrepancies between the satellite images of the area and the actual situation, the procedure of selection of the sites was repeated (the selection of plots $34,55,62$, and 75 was repeated once).

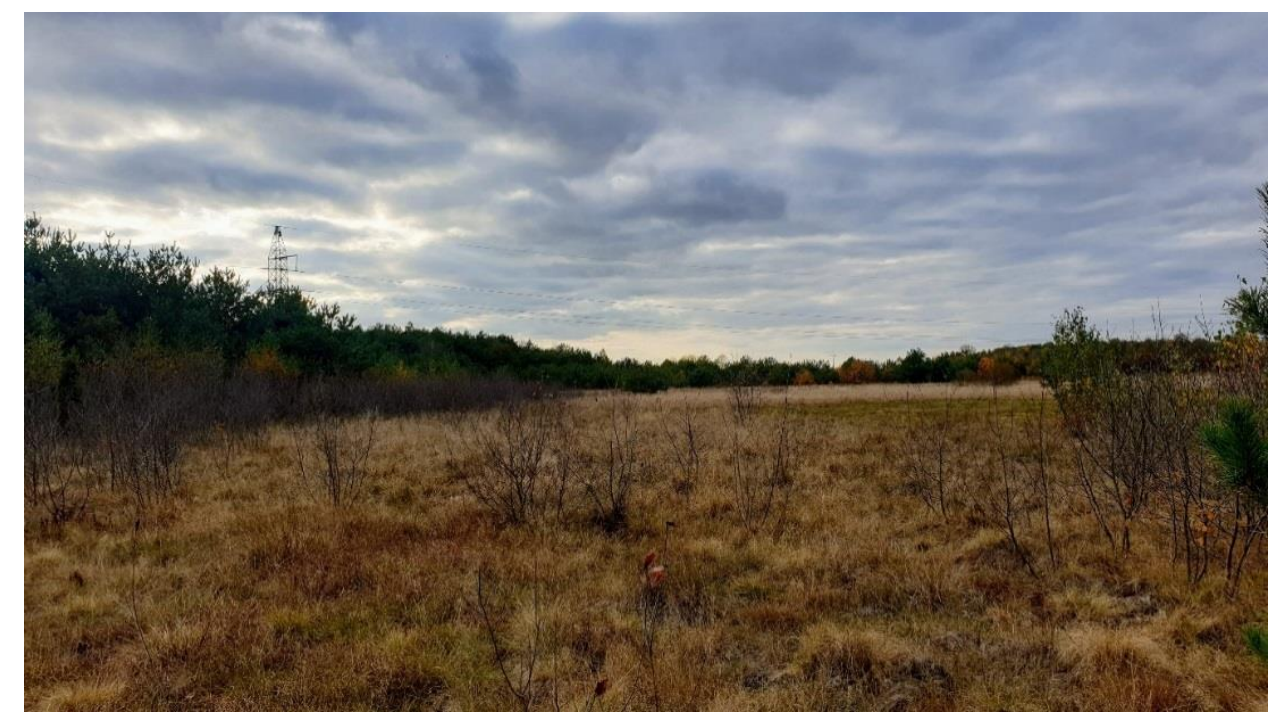

Figure 4. Site of tick collection, plot 17.

\subsection{Tick Surveillance}

D. reticulatus ticks were collected in Polesie National Park in 2014-2019. In 2014-2018, the ticks were collected at equal 14-20 day intervals. Month-long intervals were used for collection of ticks in 2019. Each time, the ticks were collected between 11:00 and 14:00 with the flagging method, in accordance with the procedure described by Nowak-Chmura [44]. Throughout the study period in Polesie National Park, the ticks were collected by the same person. The vegetation was swept with a $1 \mathrm{~m}^{2}$ white sheet each time for $30 \mathrm{~min}$. A $100 \mathrm{~m}$ long and $1 \mathrm{~m}$ wide transect was covered, which corresponds approximately to $100 \mathrm{~m}^{2}$. The sheet was inspected approximately every $2 \mathrm{~min}$ and the attached ticks were removed using forceps, placed in a container, and transported to the central laboratory.

The investigations of the tick density in Lublin Province were conducted during seasonal peaks of tick activity in this region indicated in the literature $[43,45,46]$, based on the results of studies of the seasonal activity of $D$. reticulatus ticks in Polesie National Park (Table A1 in Appendix A) and concurrent tick surveillance of the $D$. reticulatus activity in different areas of Lublin Province. The tick surveillance was conducted in the spring from 18 to 31 March 2019, and from 12 to 24 October 2019 in the autumn. Plot 93 was excluded during the autumn due to ongoing construction. Ticks were collected with the standard flagging method. Vegetation was swept with $1 \mathrm{~m}^{2}$ white flannel fabric. Each time, the ticks were collected from a $100 \mathrm{~m}^{2}$ plot. This area was flagged over a distance of $10 \mathrm{~m}$ and then the flag was checked for the presence of ticks on both sides (Figure 5). This was repeated 
10 times to ensure that the entire surface area had been swept. The ticks were collected once in the spring and once in the autumn, each time from exactly the same $100 \mathrm{~m}^{2}$ area.

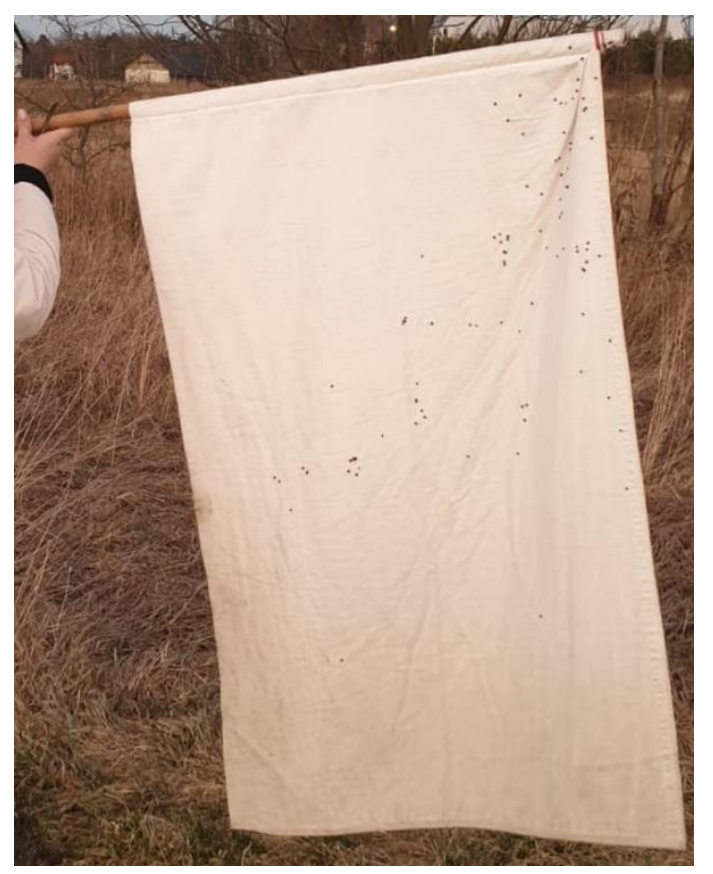

Figure 5. Dermacentor reticulatus ticks collected in plot 41. A total of 96 adult specimens were collected in an area of $10 \mathrm{~m}^{2}$.

In both stages, the current weather conditions, temperature, and relative air humidity were measured using Data Logger R6030 (Reed Instruments, Wilmington, NC, USA). In the laboratory, the species and sex of collected specimens were identified with the use of a stereoscopic microscope Zeiss STEMI DV4 (Carl Zeiss Light Microscopy, Göttingen, Germany) and an identification guide compiled by Estrada-Peña et al. [47].

\subsection{Analysis of the Land Structure of the Study Area}

The Google Maps and a layer of satellite images of the region [48] were used for calculation of the land use structure in each plot of the superimposed cartographic grid. The area of cultivated fields (arable land), forests, and meadows (grasslands) was calculated in this way. The designation "other" referred to buildings, water reservoirs, and areas that could not be clearly defined.

\subsection{Statistical Analysis}

Differences in the number of active D. reticulatus females and males in each experimental plot were analyzed statistically using the Wilcoxon signed-rank test. The Kruskal-Wallis test was used for statistical analysis of the number of active D. reticulatus females and males in the spring and autumn periods.

A multiple regression model and Spearman's rank correlation tests were used to assess the impact of the land use on tick densities. The effect of temperature and relative humidity on tick activity in Polesie National Park was evaluated using the Kruskal-Wallis test.

The statistical analysis was conducted using Statistica 10PL (StatSoft, TIBCO Software Inc, Palo Alto, CA, USA) software, and the significance level for all statistical tests was $p<0.05$. 


\section{Results}

\subsection{Multiannual Monitoring of the Seasonal Activity of D. reticulatus Ticks}

In Polesie National Park, a statistically significant $(\mathrm{H}=6.98, p=0.047)$ tendency towards increased numbers of active D. reticulatus was observed every year in 2014-2018. Higher numbers of active ticks were reported in the autumn. Concurrently, higher numbers of females than males were collected. In 2019, there were changes in the seasonal activity of D. reticulatus, as higher numbers of active ticks were collected in the spring (on average 165.5 individuals per collection event: 97 females and 68.5 males) than in the autumn (on average 46.5 individuals per collection event: 28.5 females and 18 males) (Table 1). Throughout the study, the seasonal activity (spring-autumn) of D. reticulatus ticks was significantly influenced by the air temperature prevailing during tick collection $(\mathrm{H}=12.887$, $p=0.002)$.

Table 1. Mean values of D. reticulatus ticks collected in Polesie National Park per $100 \mathrm{~m}^{2}$.

\begin{tabular}{|c|c|c|c|c|c|c|c|c|c|c|c|c|}
\hline \multirow{2}{*}{ Year } & \multicolumn{6}{|c|}{ Spring } & \multicolumn{6}{|c|}{ Autumn } \\
\hline & $n$ & $\mathrm{~T}\left[{ }^{\circ} \mathrm{C}\right]$ & H [\%] & $F$ & $\mathbf{M}$ & $\mathrm{F}+\mathrm{M}$ & $n$ & $\mathrm{~T}\left[{ }^{\circ} \mathrm{C}\right]$ & $\mathbf{H}[\%]$ & $F$ & $\mathbf{M}$ & $F+M$ \\
\hline 2014 & 6 & 11.8 & 77.2 & 10.3 & 6.8 & 17.1 & 3 & 23.0 & 72.2 & 26.6 & 22.7 & 49.3 \\
\hline 2015 & 7 & 14.9 & 69.3 & 11.1 & 7.0 & 18.1 & 4 & 20.8 & 76.3 & 21.0 & 19.2 & 40.2 \\
\hline 2016 & 6 & 12.8 & 81.0 & 10.2 & 8.3 & 18.5 & 4 & 18.1 & 68.2 & 27.0 & 17.5 & 44.5 \\
\hline 2017 & 6 & 13.4 & 77.2 & 13.8 & 13.2 & 27.0 & 5 & 17.8 & 75.4 & 25.6 & 19.4 & 45.0 \\
\hline 2018 & 3 & 12.7 & 79.0 & 41.3 & 37.0 & 78.3 & 2 & 21.0 & 68.0 & 77.5 & 60.0 & 137.0 \\
\hline 2019 & 2 & 13.5 & 80.2 & 97 & 68.5 & 165.5 & 2 & 19.8 & 74.6 & 28.5 & 18 & 46.5 \\
\hline
\end{tabular}

\subsection{Density of D. reticulatus Ticks}

A total of 19,559 adult (11,598 females and 7961 males) D. reticulatus were collected throughout the study period (Table A2). The mean number of ticks collected in Lublin Province was 96.8 specimens $/ 100 \mathrm{~m}^{2}$, with a significant dominance of females (on average 57.6 females and 39.2 males $\left./ 100 \mathrm{~m}^{2}\right)(\mathrm{Z}=8.19, p<0.001)$. The adult tick population densities were higher in the autumn than in the spring (Table 2, Table A2).

Table 2. Mean density of D. reticulatus ticks per $100 \mathrm{~m}^{2}$ in Lublin Province.

\begin{tabular}{cccccccc}
\hline $\begin{array}{c}\text { Study } \\
\text { Period }\end{array}$ & Sex & $\boldsymbol{n}$ & $\begin{array}{c}\text { Mean } \\
\text { Numbers }\end{array}$ & SD & Median & Min & Max \\
\hline \multirow{3}{*}{ Spring } & $\mathrm{F}$ & 101 & 56.5 & 50.6 & 41.0 & 4.0 & 297.0 \\
& $\mathrm{M}$ & 101 & 38.4 & 34.8 & 25.0 & 1.0 & 219.0 \\
& $\mathrm{~F}+\mathrm{M}$ & 101 & 94.9 & 83.4 & 68.0 & 5.0 & 516.0 \\
\hline \multirow{2}{*}{ Autumn } & $\mathrm{F}$ & 100 & 58.9 & 51.3 & 41.0 & 2.0 & 248.0 \\
& $\mathrm{M}$ & 100 & 40.9 & 33.5 & 30.0 & 1.0 & 135.0 \\
Whole & $\mathrm{F}+\mathrm{M}$ & 100 & 98.9 & 83.3 & 67.0 & 0.0 & 370.0 \\
study & $\mathrm{F}$ & 101 & 57.5 & 44.4 & 43.5 & 3.0 & 224.5 \\
period & $\mathrm{M}$ & 101 & 39.5 & 28.3 & 31.5 & 2.5 & 128.5 \\
\hline
\end{tabular}

SD—standard deviation, $n$ —number of plots, F-females, M-males, Min—minimum, Max—Maximum.

While the density of $D$. reticulatus in Lublin Province was high, the mean numbers were unevenly distributed (Figure 6). The highest numbers of ticks were collected in the northern part of the study area (plots 1-18; South Podlasie and Western Polesie), which varied from 86 specimens with a clear dominance of females over males (on average 53 females and 33 males) to 311 specimens/100 m² (224 females and 86.5 males). The highest density of $D$. reticulatus ticks throughout the study period was observed in plot 69, located in Lublin Upland (Figure 4). During a single collection event at the 
spring activity peak, 516 adults $/ 100 \mathrm{~m}^{2}$ of the ornate cow tick were collected, including 297 females and 219 males (Figure 6, Table A2). Low mean numbers of adults, ranging from 10 to 100 specimens/100 $\mathrm{m}^{2}$, were collected from nearby sites (located in the same macro-region) (Figure 6, Table A2). The lowest number of adult $D$. reticulatus was collected in the central part of the province, in plot 67 , with 5 ticks/100 $\mathrm{m}^{2}$ (with an average of 3 females and 2.5 males) (Figure 6, Table A2).

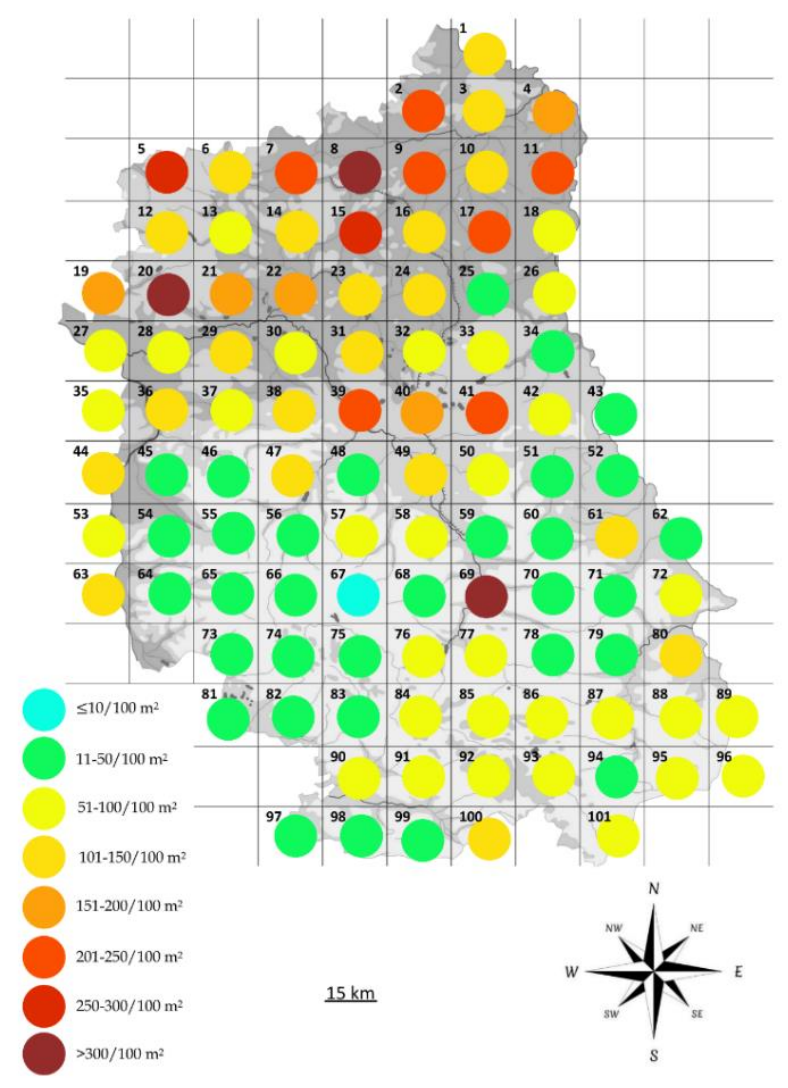

Figure 6. Spatial distribution of the average density of D. reticulatus populations in Lublin Province, the map outline based on Wikimedia [42] with our own modifications.

At the peak of the seasonal (spring and autumn) activity of D. reticulatus ticks in Lublin Province, there were differences in the distribution of tick density. The northern, southern, and western parts of the Lublin region were characterized by a higher density of $D$. reticulatus ticks in the autumn, while a higher density in the spring was noted in the central and eastern parts of the area (Table A2, Figure 6).

The density of the ornate cow tick based on ecological variables (arable fields, forests, meadows) was not significantly different $\left(\mathrm{F}_{(3.97)}=1.05, p=0.3728\right)$. However, the analysis of Spearman's rank correlation coefficient indicated that the density of $D$. reticulatus (both females and males) rose with increased meadow area ( $\mathrm{Rs}=0.281, p=0.0044)$.

\section{Discussion}

Population densities of $D$. reticulatus are dependent upon biotic and abiotic factors. The most important factors include the presence of potential hosts, ecological habitats, climatic factors, photoperiod, excreted semiochemical substances, and hormones controlling the rhythms of seasonal activity, diapause periods, and biology of tick reproduction and development [12,49].

In Eastern Poland, the greatest impact on the seasonal (spring-autumn) and diurnal rhythms of $D$. reticulatus activity is exerted by air temperatures prevailing during tick collection $[43,45]$. This dependence is supported by the results of multiyear monitoring of seasonal tick activity in Polesie 
National Park. Together with relative humidity, it can affect the ticks' questing behavior [50] and locomotor activity [51].

The area of Lublin Province has the highest density of tick populations (mean 96.8 specimens $/ 100 \mathrm{~m}^{2}$ ) of all studied areas in Poland. The mean number of adult $D$. reticulatus collected in Lublin Province was 13.1-fold higher than in Mazovia (Central Poland; mean 7.4 ticks $/ 100 \mathrm{~m}^{2}$ from 2012-2014), 15.6-fold higher than in Lubuskie Province (Western Poland; mean 6.29 ticks/100 $\mathrm{m}^{2}$ from 2012-2014), and 32.3-fold higher than in the West Pomeranian Province (North-Western Poland; mean 3.04 ticks $/ 100 \mathrm{~m}^{2}$ from 2012-2014) [20].

The northern and northeastern regions of Lublin Province are characterized by a high density of $D$. reticulatus ticks (Figure 6, Table A2). These areas have the largest proportion of grasslands in the entire province, and an increase in their surface area correlates positively and has a significant statistical effect on the number of collected ticks. A significant percentage of land in this area is also occupied by fallows and wasteland, as well as forest islands. The mosaic character of the landscape offers favorable conditions for the development of $D$. reticulatus populations. Forest areas provide availability of hosts of adult stages, whereas meadows and wasteland are preferable habitats for rodents, which are the hosts of juvenile ticks.

The highest island density of D. reticulatus ticks (516 specimens $/ 100 \mathrm{~m}^{2}$ ) was observed in plot 69 , located in the central part of the region (Figure 6). Of note, the tick densities in the neighboring sites (located in the same macro-region) were among the lowest in the entire study area, and ranged from 10 to 57 specimens $/ 100 \mathrm{~m}^{2}$ (Figure 6, Table A2). Such a high island density of ornate cow ticks is associated with the ecology of the habitats. The site where the maximum number of ticks was caught is surrounded by an abandoned meadow, watercourse, and forest in close proximity, while the forest cover in the entire macro-region is $<8 \%$ (average for the province: $22 \%$ ) (Table A2).

As demonstrated by Mierzejewska et al. [52], the spread of D. reticulatus is associated with the loss of forest area. We share this opinion, with the provision that excessive tree felling does not result in conversion of the land into intensively used agricultural areas. In the study area, the lowest average density of ornate cow ticks was observed in Lublin Upland, a region that is intensively used for agriculture due to its fertile soils. The impact of large forest areas on the density of ornate cow ticks is observed in Lublin Province as well. The number of ticks collected in plots 73 and 74 (forest cover $>61 \%$, meadow area $1.93 \%-4.09 \%$ ), located within the biggest forest of Lublin Province ("Janów Forest"), was significantly lower than the average number for the region of 29 and 23 specimens $/ 100 \mathrm{~m}^{2}$ in spring and 46 and 30 specimens $/ 100 \mathrm{~m}^{2}$ in autumn, respectively (Table A2). The results of our studies show that $D$. reticulatus populations can persist and steadily develop only in areas with appropriate proportions of forests and meadows/fallow lands. Nevertheless, isolated populations of $D$. reticulatus ticks can exist in habitats where these proportions are disturbed.

D. reticulatus ticks mostly exhibit two distinct peaks of seasonal activity in spring and autumn. In the French Alps, the European part of Russia, and North-Eastern Poland, more ticks are active in spring $[12,53,54]$. The data published so far indicate that the number of ticks collected in autumn in Eastern Poland is three-fold higher than in spring $[43,45,46]$. Our research results show that the seasonal activity may change within the same population, even if it is recognized as stable (Table 1). The D. reticulatus population in Polesie National Park, monitored by us for the last 6 years (Table 1), exhibited a clearly higher number of active ticks in autumn in 2014-2018 and dominance of the spring peak of activity over autumn in 2019, with a ratio of 3.5:1 (Table 1). Since the experimental field is located within a protected area, the anthropogenic impact is limited. We believe that the size and dynamics of the $D$. reticulatus seasonal activity are influenced mostly by the availability of preferred hosts occurring in the investigated area, such as roe deer (Capreolus capreolus), deer (Cervus elaphus), elk (Alces alces), and wild boar (Sus scrofa). Our unpublished observations demonstrate the highest degree of ornate cow tick infestations in wild boars. These animals occur in the entire province and their population size has been growing over recent years, by as much as $178 \%$, or from 6400 to 17,800 
specimens within 5 years. For comparison, there were 2300 elks and 7600 deer in the area at the same time [55].

In 2017-2018, a decrease in the size of wild boar populations was observed in Lublin Province due to confirmed outbreaks of African swine fever (ASF). Before April 2018, the mortality caused by this viral disease was 1942 wild boars in Eastern Poland [56]. Furthermore, during this period, the wild boar population was reduced preventively. At the turn of 2018/2019, the estimated size of the wild boar population in the Province declined to "no more than several hundred individuals" (personal communication with the Lublin Hunting Association). This led to a significant decrease in the number of animals that are one of the main hosts of $D$. reticulatus $[57,58]$. In our opinion, this situation is reflected in the structure of the population size and the dynamics of seasonal activity of $D$. reticulatus populations in Eastern Poland. It also explains the differences in the spatial distribution of the density of this tick species in Lublin Province. Considering the over 2-year survival of adult specimens in a habitat [12], the predominance of tick activity in spring in areas where an autumn peak was noted previously [43] could be associated with insufficient numbers of hosts for the adult ornate cow ticks in this period. Nevertheless, impacts from other factors on this phenomenon should not be excluded, and further observations and investigations are required.

The high density of $D$. reticulatus ticks in Lublin Province is associated with a greater risk of tick attack on animals, and sporadically on humans, than in other country regions, and therefore an increased threat of transmission of tick-borne pathogens. Various pathogens have been detected in ornate cow ticks, including Anaplasma phagocytophilum, Rickettsia raoultii, Borrelia burgdorferi s. 1., Babesia spp., and TBE virus $[59,60]$. An increase in the tick population density may result in an increased incidence of tick-borne diseases in future [61]. Numerous cases of canine babesiosis and domestic animal borreliosis have already been reported [62-64].

\section{Conclusions}

D. reticulatus ticks occur throughout the entire area of Lublin Province. This region is characterized by a very high density of the ornate cow tick. However, it is unevenly distributed. Changes in land use may influence the size of local $D$. reticulatus populations. An increase in the surface of meadows, grasslands, and fallow land contribute to a rise in the number of ornate cow ticks, whereas afforestation of new areas may reduce their population size.

The local $D$. reticulatus population exhibits differences in its peaks of seasonal activity. The highest risk of $D$. reticulatus infestations of animals and humans occurs in spring in the eastern and central parts of the region, and in autumn in the northern and western parts of the province.

Author Contributions: Conceptualization, Z.Z.; methodology, Z.Z.; software, Z.Z., A.W.; validation, Z.Z., A.W. and J.K.; formal analysis, A.W., J.K.; investigation, Z.Z., A.W. and J.K.; resources, Z.Z., A.W. and J.K.; data curation, A.W. and J.K.; writing-original draft preparation, Z.Z.; writing—review and editing, A.W., J.K.; Supervision, Z.Z.; visualization, Z.Z.; project administration, Z.Z. All authors have read and agreed to the published version of the manuscript.

Funding: This research received no external funding.

Acknowledgments: The authors thank the authorities of the Ministry of the Environment for their consent (DOP-WPN.286.312.2019.MD and DLP-III-4102/16/1278/15/MD) for conducting the research in the protected area of Polesie National Park. We also thank Katarzyna Bartosik and Monika Jung for their help in the field studies.

Conflicts of Interest: The authors declare no conflict of interest. 


\section{Appendix A}

Table A1. Seasonal activity of D. reticulatus ticks in Polesie National Park in 2014-2019 per $100 \mathrm{~m}^{2}$.

\begin{tabular}{|c|c|c|c|}
\hline Collection Date & $\mathbf{F}$ & $\mathbf{M}$ & $\mathbf{F}+\mathrm{M}$ \\
\hline 23 March 2014 & 15 & 10 & 25 \\
\hline 8 April 2014 & 15 & 5 & 20 \\
\hline 23 April 2014 & 8 & 5 & 13 \\
\hline 1 May 2014 & 10 & 8 & 18 \\
\hline 10 May 2014 & 10 & 6 & 16 \\
\hline 20 May 2014 & 4 & 7 & 11 \\
\hline 17 September 2014 & 18 & 18 & 36 \\
\hline 15 October 2014 & 29 & 30 & 59 \\
\hline 29 October 2014 & 33 & 20 & 53 \\
\hline 21 March 2015 & 18 & 15 & 33 \\
\hline 1 April 2015 & 15 & 10 & 25 \\
\hline 11 April 2015 & 13 & 8 & 21 \\
\hline 25 April 2015 & 17 & 3 & 20 \\
\hline 1 May 2015 & 5 & 8 & 13 \\
\hline 23 May 2015 & 5 & 5 & 10 \\
\hline 5 June 2015 & 5 & 0 & 5 \\
\hline 12 September 2015 & 22 & 24 & 46 \\
\hline 26 September 2015 & 20 & 18 & 38 \\
\hline 12 October 2015 & 30 & 19 & 49 \\
\hline 2 November 2015 & 12 & 16 & 28 \\
\hline 5 March 2016 & 13 & 10 & 23 \\
\hline 4 April 2016 & 8 & 12 & 20 \\
\hline 16. April 2016 & 12 & 12 & 20 \\
\hline 30 April 2016 & 10 & 8 & 18 \\
\hline 7 May 2016 & 8 & 3 & 11 \\
\hline 3 June 2016 & 10 & 5 & 15 \\
\hline 9 September 2016 & 22 & 11 & 33 \\
\hline 20 September 2016 & 17 & 14 & 31 \\
\hline 30 September 2016 & 30 & 25 & 55 \\
\hline 20 October 2016 & 39 & 20 & 59 \\
\hline 10 March 2017 & 8 & 12 & 20 \\
\hline 20 March 2017 & 28 & 20 & 48 \\
\hline 1 April 2017 & 15 & 21 & 36 \\
\hline 19 April 2017 & 6 & 8 & 14 \\
\hline 25 April 2017 & 13 & 10 & 23 \\
\hline 10 May 2017 & 13 & 8 & 21 \\
\hline 5 September 2017 & 14 & 10 & 24 \\
\hline 20 September 2017 & 30 & 33 & 63 \\
\hline 27 September 2017 & 25 & 26 & 51 \\
\hline 11 October 2017 & 20 & 8 & 28 \\
\hline 18 October 2017 & 39 & 20 & 59 \\
\hline 12 March 2018 & 31 & 35 & 66 \\
\hline 24 March 2018 & 62 & 35 & 97 \\
\hline 30 March 2018 & 31 & 41 & 72 \\
\hline 19 September 2018 & 61 & 29 & 90 \\
\hline 19 September 2018 & 94 & 91 & 185 \\
\hline 1 March 2019 & 55 & 70 & 125 \\
\hline 28 March 2019 & 139 & 67 & 206 \\
\hline 19 September 2019 & 11 & 17 & 28 \\
\hline 10 October 2019 & 46 & 19 & 65 \\
\hline
\end{tabular}

$\mathrm{F}$-females, $\mathrm{M}$-males. 
Table A2. Structure of land use and density of D. reticulatus ticks per $100 \mathrm{~m}^{2}$ in the study area.

\begin{tabular}{|c|c|c|c|c|c|c|c|c|c|c|c|c|c|c|c|c|c|}
\hline \multirow{4}{*}{$\begin{array}{c}\text { Plot } \\
\text { Number/Regions }\end{array}$} & \multirow{2}{*}{\multicolumn{4}{|c|}{ Landscape Structure }} & \multicolumn{13}{|c|}{ Ticks Density Per $100 \mathrm{~m}^{2}$} \\
\hline & & & & & \multicolumn{5}{|c|}{ Spring } & \multicolumn{5}{|c|}{ Autumn } & \multirow{2}{*}{\multicolumn{3}{|c|}{\begin{tabular}{|c|} 
Total Study Period \\
Mean Tick Density
\end{tabular}}} \\
\hline & \multirow{2}{*}{$\begin{array}{c}\text { Farmlands } \\
{[\%]}\end{array}$} & \multirow[t]{2}{*}{ Forests $[\%]$} & \multirow{2}{*}{$\begin{array}{c}\text { Meadows } \\
{[\%]}\end{array}$} & \multirow[t]{2}{*}{ Other [\%] } & \multicolumn{2}{|c|}{$\begin{array}{c}\text { Weather } \\
\text { Parameters }\end{array}$} & \multicolumn{3}{|c|}{ Tick Density } & \multicolumn{2}{|c|}{$\begin{array}{c}\text { Weather } \\
\text { Parameters }\end{array}$} & \multicolumn{3}{|c|}{ Tick Density } & & & \\
\hline & & & & & $\mathrm{T}\left[{ }^{\circ} \mathrm{C}\right]$ & $\mathrm{H}[\%]$ & $F$ & $\mathbf{M}$ & $\mathrm{F}+\mathrm{M}$ & $\mathrm{T}\left[{ }^{\circ} \mathrm{C}\right]$ & $\mathrm{H}[\%]$ & $F$ & $\mathbf{M}$ & $\mathrm{F}+\mathrm{M}$ & $F$ & M & $F+M$ \\
\hline 1 & 67.21 & 13.5 & 5.21 & 14.08 & 12.1 & 88.8 & 84 & 54 & 138 & 22.5 & 60.0 & 98 & 61 & 159 & 91 & 57.5 & 148.5 \\
\hline 2 & 68.00 & 20.65 & 5.98 & 5.37 & 10.8 & 87.0 & 105 & 75 & 180 & 21.8 & 70.6 & 150 & 122 & 272 & 127.5 & 98.5 & 226 \\
\hline 3 & 61.00 & 15.59 & 5.23 & 18.18 & 13.4 & 90.6 & 29 & 14 & 43 & 23.2 & 70.1 & 100 & 69 & 169 & 64.5 & 41.5 & 106 \\
\hline 4 & 55.11 & 29.96 & 7.99 & 6.94 & 13.5 & 80.5 & 74 & 51 & 125 & 23.1 & 70.6 & 112 & 82 & 194 & 93 & 66.5 & 159.5 \\
\hline 5 & 79.56 & 5.66 & 2.05 & 12.73 & 14.1 & 86.0 & 153 & 93 & 246 & 19.6 & 81.0 & 177 & 106 & 283 & 165 & 99.5 & 264.5 \\
\hline 6 & 65.12 & 18.20 & 6.78 & 9.90 & 15.1 & 75.4 & 45 & 25 & 70 & 20.5 & 67.5 & 130 & 96 & 226 & 87.5 & 60.5 & 148 \\
\hline 7 & 80.12 & 10.10 & 4.11 & 5.67 & 14.8 & 81.2 & 105 & 66 & 171 & 22.5 & 66.0 & 164 & 102 & 266 & 134.5 & 84 & 218.5 \\
\hline 8 & 64.99 & 18.70 & 6.78 & 9.53 & 14.7 & 70.0 & 201 & 51 & 252 & 23.4 & 72.5 & 248 & 122 & 370 & 224.5 & 86.5 & 311 \\
\hline 9 & 40.00 & 45.03 & 6.50 & 8.47 & 17.5 & 77.0 & 96 & 48 & 144 & 21.0 & 77.8 & 190 & 134 & 324 & 143 & 91 & 234 \\
\hline 10 & 71.20 & 11.96 & 8.98 & 7.86 & 16.1 & 86.0 & 44 & 30 & 74 & 19.8 & 69.0 & 116 & 81 & 197 & 80 & 55.5 & 135.5 \\
\hline 11 & 55.10 & 30.11 & 8.21 & 6.58 & 14.5 & 70.5 & 93 & 93 & 186 & 20.0 & 54.2 & 170 & 110 & 280 & 131.5 & 101.5 & 233 \\
\hline 12 & 73.30 & 16.41 & 6.10 & 4.19 & 12.9 & 77.9 & 26 & 19 & 45 & 18.5 & 70.5 & 145 & 98 & 243 & 85.5 & 58.5 & 144 \\
\hline 13 & 85.23 & 4.29 & 2.70 & 7.78 & 15.0 & 84.2 & 31 & 36 & 67 & 17.5 & 81.2 & 56 & 36 & 92 & 43.5 & 36 & 79.5 \\
\hline 14 & 77.40 & 13.04 & 1.80 & 7.76 & 12.1 & 81.8 & 75 & 39 & 114 & 16.1 & 84.2 & 88 & 24 & 112 & 81.5 & 31.5 & 113 \\
\hline 15 & 83.90 & 3.61 & 6.67 & 5.82 & 13.7 & 74.0 & 123 & 87 & 210 & 15.1 & 75.9 & 196 & 108 & 304 & 159.5 & 97.5 & 257 \\
\hline 16 & 65.21 & 18.47 & 7.45 & 8.87 & 11.9 & 86.1 & 84 & 42 & 126 & 13.9 & 77.7 & 99 & 55 & 154 & 91.5 & 48.5 & 140 \\
\hline 17 & 60.21 & 25.00 & 7.00 & 7.79 & 15.6 & 82.0 & 102 & 81 & 183 & 18.8 & 78.3 & 190 & 100 & 290 & 146 & 90.5 & 236.5 \\
\hline 18 & 55.12 & 30.56 & 6.12 & 8.20 & 16.1 & 76.0 & 42 & 35 & 77 & 20.5 & 71.0 & 64 & 31 & 95 & 53 & 33 & 86 \\
\hline 19 & 65.12 & 24.87 & 3.15 & 6.86 & 18.5 & 67.0 & 68 & 56 & 124 & 16.9 & 79.9 & 133 & 70 & 203 & 100.5 & 63 & 163.5 \\
\hline 20 & 65.18 & 17.30 & 7.87 & 9.65 & 22.0 & 66.0 & 166 & 122 & 288 & 21.0 & 65.7 & 180 & 135 & 315 & 173 & 128.5 & 301.5 \\
\hline 21 & 80.99 & 6.68 & 2.10 & 10.23 & 19.5 & 69.9 & 177 & 69 & 246 & 23.0 & 69.0 & 75 & 50 & 125 & 126 & 59.5 & 185.5 \\
\hline 22 & 70.36 & 21.67 & 3.98 & 3.99 & 15.4 & 78.9 & 129 & 99 & 228 & 22.0 & 54.9 & 60 & 64 & 124 & 94.5 & 81.5 & 176 \\
\hline 23 & 71.33 & 18.90 & 5.00 & 4.77 & 16.7 & 69.2 & 100 & 65 & 165 & 19.8 & 55.0 & 62 & 41 & 103 & 81 & 53 & 134 \\
\hline 24 & 60.12 & 25.53 & 7.00 & 7.35 & 14.8 & 67.0 & 141 & 75 & 216 & 17.5 & 87.0 & 36 & 18 & 54 & 88.5 & 46.5 & 135 \\
\hline 25 & 45.00 & 39.56 & 7.11 & 8.33 & 10.5 & 90.5 & 15 & 13 & 28 & 16.4 & 80.0 & 20 & 50 & 70 & 17.5 & 31.5 & 49 \\
\hline 26 & 70.01 & 12.24 & 3.98 & 13.77 & 11.0 & 82.0 & 45 & 39 & 84 & 17.0 & 81.0 & 26 & 13 & 39 & 35.5 & 26 & 61.5 \\
\hline 27 & 50.98 & 32.11 & 3.00 & 13.91 & 19.3 & 82.8 & 22 & 11 & 33 & 13.6 & 88.0 & 66 & 22 & 88 & 44 & 16.5 & 60.5 \\
\hline 28 & 70.11 & 17.53 & 6.18 & 6.18 & 18.5 & 71.6 & 49 & 22 & 71 & 17.4 & 80.2 & 66 & 50 & 116 & 57.5 & 36 & 93.5 \\
\hline 29 & 70.96 & 11.72 & 5.23 & 12.09 & 17.1 & 75.9 & 75 & 35 & 110 & 23.1 & 65.0 & 59 & 66 & 125 & 67 & 50.5 & 117.5 \\
\hline 30 & 55.00 & 25.84 & 8.01 & 13.15 & 16.5 & 65.0 & 45 & 25 & 70 & 22.0 & 53.2 & 58 & 44 & 102 & 51.5 & 34.5 & 86 \\
\hline 31 & 40.19 & 43.67 & 5.00 & 11.14 & 10.7 & 83.0 & 61 & 50 & 111 & 24.8 & 55.0 & 84 & 68 & 152 & 72.5 & 59 & 131.5 \\
\hline 32 & 71.11 & 18.31 & 5.45 & 5.13 & 10.9 & 81.0 & 40 & 34 & 74 & 25.6 & 45.7 & 37 & 10 & 47 & 38.5 & 17 & 55.5 \\
\hline 33 & 35.23 & 56.19 & 4.00 & 4.58 & 13.5 & 73.5 & 25 & 18 & 43 & 24.0 & 58.0 & 62 & 35 & 97 & 43.5 & 26.5 & 70 \\
\hline 34 & 14.18 & 72.00 & 9.12 & 4.70 & 13.0 & 79.0 & 18 & 11 & 29 & 20.9 & 74.8 & 15 & 5 & 20 & 16.5 & 8 & 24.5 \\
\hline 35 & 69.27 & 19.45 & 5.00 & 6.28 & 14.0 & 65.8 & 26 & 17 & 43 & 14.5 & 80.0 & 30 & 32 & 62 & 28 & 24.5 & 52.5 \\
\hline 36 & 78.16 & 8.00 & 7.12 & 6.72 & 13.7 & 58.9 & 69 & 96 & 165 & 15.6 & 69.0 & 60 & 58 & 118 & 64.5 & 77 & 141.5 \\
\hline 37 & 80.50 & 2.03 & 5.90 & 11.57 & 11.0 & 70.0 & 58 & 60 & 118 & 20.5 & 73.3 & 34 & 26 & 60 & 46 & 43 & 89 \\
\hline 38 & 80.10 & 9.06 & 4.17 & 6.67 & 9.5 & 79.0 & 144 & 81 & 225 & 22.0 & 60.0 & 14 & 12 & 26 & 79 & 46.5 & 125.5 \\
\hline
\end{tabular}


Table A2. Cont.

\begin{tabular}{|c|c|c|c|c|c|c|c|c|c|c|c|c|c|c|c|c|c|}
\hline \multirow{4}{*}{$\begin{array}{c}\text { Plot } \\
\text { Number/Regions }\end{array}$} & \multirow{2}{*}{\multicolumn{4}{|c|}{ Landscape Structure }} & \multicolumn{13}{|c|}{ Ticks Density Per $100 \mathrm{~m}^{2}$} \\
\hline & & & & & \multicolumn{5}{|c|}{ Spring } & \multicolumn{5}{|c|}{ Autumn } & \multirow{2}{*}{\multicolumn{3}{|c|}{$\begin{array}{c}\text { Total Study Period } \\
\text { Mean Tick Density }\end{array}$}} \\
\hline & \multirow{2}{*}{$\begin{array}{c}\text { Farmlands } \\
{[\%]}\end{array}$} & \multirow[t]{2}{*}{ Forests $[\%]$} & \multirow{2}{*}{$\begin{array}{c}\text { Meadows } \\
{[\%]}\end{array}$} & \multirow[t]{2}{*}{ Other [\%] } & \multicolumn{2}{|c|}{$\begin{array}{c}\text { Weather } \\
\text { Parameters }\end{array}$} & \multicolumn{3}{|c|}{ Tick Density } & \multicolumn{2}{|c|}{$\begin{array}{c}\text { Weather } \\
\text { Parameters }\end{array}$} & \multicolumn{3}{|c|}{ Tick Density } & & & \\
\hline & & & & & $\mathrm{T}\left[{ }^{\circ} \mathrm{C}\right]$ & $\mathrm{H}[\%]$ & $F$ & $\mathbf{M}$ & $\mathrm{F}+\mathrm{M}$ & $\mathrm{T}\left[{ }^{\circ} \mathrm{C}\right]$ & $\mathrm{H}[\%]$ & $F$ & $\mathbf{M}$ & $\mathrm{F}+\mathrm{M}$ & $F$ & M & $\mathrm{F}+\mathrm{M}$ \\
\hline 39 & 68.00 & 16.29 & 5.22 & 4.49 & 12.5 & 78.0 & 181 & 98 & 279 & 23.0 & 62.4 & 84 & 66 & 150 & 132.5 & 82 & 214.5 \\
\hline 40 & 60.05 & 25.24 & 7.01 & 7.70 & 13.1 & 85.0 & 120 & 111 & 231 & 21.0 & 55.8 & 58 & 30 & 88 & 89 & 70.5 & 159.5 \\
\hline 41 & 65.19 & 14.06 & 8.08 & 12.67 & 13.0 & 68.9 & 194 & 137 & 331 & 22.1 & 67.0 & 57 & 36 & 93 & 125.5 & 86.5 & 212 \\
\hline 42 & 50.00 & 40.00 & 5.23 & 4.77 & 14.9 & 60.1 & 80 & 60 & 140 & 20.5 & 73.8 & 15 & 6 & 21 & 47.5 & 33 & 80.5 \\
\hline 43 & 30.12 & 60.00 & 4.00 & 5.88 & 12.0 & 68.3 & 44 & 22 & 66 & 23.5 & 73.0 & 16 & 22 & 38 & 30 & 22 & 52 \\
\hline 44 & 61.87 & 23.32 & 2.55 & 12.26 & 14.7 & 67.0 & 63 & 66 & 129 & 16.9 & 83.8 & 85 & 80 & 165 & 74 & 73 & 147 \\
\hline 45 & 80.99 & 9.26 & 2.99 & 6.76 & 13.0 & 78.0 & 35 & 18 & 53 & 18.0 & 80.6 & 4 & 12 & 16 & 19.5 & 15 & 34.5 \\
\hline 46 & 90.01 & 1.35 & 1.81 & 6.83 & 11.0 & 77.0 & 10 & 8 & 18 & 23.5 & 75.5 & 32 & 20 & 52 & 21 & 14 & 35 \\
\hline 47 & 50.09 & 6.01 & 5.00 & 38.90 & 9.1 & 85.0 & 46 & 36 & 82 & 25.7 & 49.0 & 90 & 61 & 151 & 68 & 48.5 & 116.5 \\
\hline 48 & 58.98 & 29.05 & 4.90 & 7.07 & 8.5 & 88.0 & 28 & 18 & 46 & 23.0 & 57.0 & 20 & 26 & 46 & 24 & 22 & 46 \\
\hline 49 & 70.76 & 13.03 & 6.98 & 9.23 & 12.0 & 80.0 & 82 & 60 & 142 & 21.9 & 69.8 & 80 & 71 & 151 & 81 & 65.5 & 146.5 \\
\hline 50 & 76.32 & 13.50 & 4.12 & 6.06 & 12.9 & 83.5 & 44 & 40 & 84 & 22.0 & 74.0 & 16 & 11 & 27 & 30 & 25.5 & 55.5 \\
\hline 51 & 64.95 & 18.73 & 4.76 & 11.56 & 12.6 & 81.1 & 30 & 18 & 48 & 17.0 & 87.0 & 10 & 9 & 19 & 20 & 13.5 & 33.5 \\
\hline 52 & 65.85 & 18.31 & 5.98 & 9.86 & 13.0 & 78.8 & 21 & 12 & 33 & 12.9 & 88.0 & 12 & 7 & 19 & 16.5 & 9.5 & 26 \\
\hline 53 & 75.66 & 13.53 & 1.90 & 8.91 & 10.8 & 90.0 & 26 & 9 & 35 & 15.6 & 76.0 & 74 & 77 & 151 & 50 & 43 & 93 \\
\hline 54 & 76.98 & 13.04 & 1.40 & 8.58 & 12.0 & 81.5 & 18 & 24 & 42 & 19.9 & 73.1 & 32 & 20 & 52 & 25 & 22 & 47 \\
\hline 55 & 80.01 & 6.03 & 1.00 & 12.96 & 15.9 & 75.0 & 12 & 16 & 28 & 17.8 & 72.7 & 29 & 12 & 41 & 20.5 & 14 & 34.5 \\
\hline 56 & 82.03 & 6.20 & 3.09 & 8.68 & 17.5 & 74.1 & 36 & 20 & 56 & 17.0 & 60.6 & 10 & 2 & 12 & 23 & 11 & 34 \\
\hline 57 & 79.06 & 8.30 & 5.99 & 6.65 & 14.0 & 81.0 & 56 & 48 & 104 & 13.0 & 90.0 & 14 & 9 & 23 & 35 & 28.5 & 63.5 \\
\hline 58 & 71.11 & 13.06 & 6.89 & 8.94 & 18.3 & 70.0 & 40 & 22 & 62 & 11.9 & 93.2 & 28 & 12 & 40 & 34 & 17 & 51 \\
\hline 59 & 70.20 & 15.74 & 6.34 & 7.72 & 16.4 & 65.3 & 18 & 16 & 34 & 15.7 & 85.2 & 16 & 22 & 38 & 17 & 19 & 36 \\
\hline 60 & 40.56 & 39.62 & 8.00 & 11.82 & 17.5 & 53.8 & 35 & 23 & 58 & 20.1 & 74.8 & 7 & 11 & 18 & 21 & 17 & 38 \\
\hline 61 & 74.58 & 10.24 & 6.12 & 9.06 & 15.0 & 67.0 & 78 & 75 & 153 & 20.0 & 67.0 & 25 & 29 & 54 & 51.5 & 52 & 103.5 \\
\hline 62 & 50.75 & 35.65 & 4.00 & 9.60 & 14.8 & 74.9 & 22 & 10 & 32 & 23.1 & 63.0 & 25 & 17 & 42 & 23.5 & 13.5 & 37 \\
\hline 63 & 80.00 & 8.16 & 2.98 & 8.86 & 10.5 & 80.3 & 45 & 12 & 57 & 19.5 & 76.9 & 84 & 76 & 160 & 64.5 & 44 & 108.5 \\
\hline 64 & 71.00 & 18.01 & 3.09 & 7.90 & 11.0 & 86.0 & 36 & 45 & 81 & 19.0 & 71.0 & 12 & 8 & 20 & 24 & 26.5 & 50.5 \\
\hline 65 & 65.07 & 15.63 & 5.01 & 14.29 & 9.1 & 80.0 & 15 & 10 & 25 & 23.3 & 46.0 & 11 & 6 & 17 & 13 & 8 & 21 \\
\hline 66 & 89.88 & 1.85 & 1.03 & 7.24 & 17.4 & 70.0 & 14 & 7 & 21 & 18.7 & 69.4 & 12 & 11 & 23 & 13 & 9 & 22 \\
\hline 67 & 80.09 & 6.71 & 2.00 & 11.20 & 21.4 & 58.8 & 4 & 1 & 5 & 16.6 & 78.0 & 2 & 4 & 6 & 3 & 2.5 & 5.5 \\
\hline 68 & 87.33 & 3.32 & 1.33 & 8.02 & 22.0 & 54.7 & 26 & 8 & 34 & 20.4 & 71.0 & 26 & 24 & 50 & 26 & 16 & 42 \\
\hline 69 & 70.45 & 17.77 & 2.03 & 9.75 & 17.0 & 55.0 & 297 & 219 & 516 & 21.1 & 72.8 & 68 & 34 & 102 & 182.5 & 126.5 & 309 \\
\hline 70 & 69.79 & 15.01 & 5.12 & 10.08 & 16.0 & 70.7 & 33 & 7 & 40 & 22.2 & 77.1 & 30 & 31 & 61 & 31.5 & 19 & 50.5 \\
\hline 71 & 70.56 & 18.76 & 2.34 & 8.34 & 16.5 & 70.0 & 18 & 15 & 33 & 20.6 & 68.5 & 29 & 31 & 60 & 23.5 & 23 & 46.5 \\
\hline 72 & 44.87 & 42.16 & 6.00 & 6.97 & 15.3 & 78.3 & 60 & 54 & 114 & 25.0 & 62.2 & 45 & 22 & 67 & 52.5 & 38 & 90.5 \\
\hline 73 & 10.00 & 85.00 & 1.93 & 3.07 & 19.5 & 75.0 & 16 & 8 & 24 & 19.0 & 70.5 & 26 & 20 & 46 & 21 & 14 & 35 \\
\hline 74 & 29.09 & 61.00 & 4.09 & 5.82 & 18.0 & 65.8 & 15 & 14 & 29 & 18.7 & 76.0 & 18 & 12 & 30 & 16.5 & 13 & 29.5 \\
\hline 75 & 75.00 & 7.45 & 1.31 & 16.24 & 18.0 & 51.2 & 12 & 11 & 23 & 16.5 & 79.1 & 19 & 6 & 25 & 15.5 & 8.5 & 24 \\
\hline 76 & 80.34 & 10.86 & 3.05 & 5.75 & 16.5 & 55.5 & 42 & 16 & 58 & 20.2 & 78.5 & 36 & 10 & 46 & 39 & 13 & 52 \\
\hline
\end{tabular}


Table A2. Cont.

\begin{tabular}{|c|c|c|c|c|c|c|c|c|c|c|c|c|c|c|c|c|c|}
\hline \multirow{4}{*}{$\begin{array}{c}\text { Plot } \\
\text { Number/Regions }\end{array}$} & \multirow{2}{*}{\multicolumn{4}{|c|}{ Landscape Structure }} & \multicolumn{13}{|c|}{ Ticks Density Per $100 \mathrm{~m}^{2}$} \\
\hline & & & & & \multicolumn{5}{|c|}{ Spring } & \multicolumn{5}{|c|}{ Autumn } & \multirow{2}{*}{\multicolumn{3}{|c|}{$\begin{array}{l}\text { Total Study Period } \\
\text { Mean Tick Density }\end{array}$}} \\
\hline & \multirow{2}{*}{$\begin{array}{c}\text { Farmlands } \\
{[\%]}\end{array}$} & \multirow[t]{2}{*}{ Forests $[\%]$} & \multirow{2}{*}{$\begin{array}{c}\text { Meadows } \\
\text { [\%] }\end{array}$} & \multirow[t]{2}{*}{ Other [\%] } & \multicolumn{2}{|c|}{$\begin{array}{c}\text { Weather } \\
\text { Parameters }\end{array}$} & \multicolumn{3}{|c|}{ Tick Density } & \multicolumn{2}{|c|}{$\begin{array}{c}\text { Weather } \\
\text { Parameters }\end{array}$} & \multicolumn{3}{|c|}{ Tick Density } & & & \\
\hline & & & & & $\mathrm{T}\left[{ }^{\circ} \mathrm{C}\right]$ & H [\%] & $\mathbf{F}$ & $\mathbf{M}$ & $\mathrm{F}+\mathrm{M}$ & $\mathrm{T}\left[{ }^{\circ} \mathrm{C}\right]$ & $\mathrm{H}[\%]$ & $\mathbf{F}$ & $\mathbf{M}$ & $\mathrm{F}+\mathrm{M}$ & F & $\mathbf{M}$ & $\mathrm{F}+\mathrm{M}$ \\
\hline 77 & 70.91 & 15.23 & 5.09 & 8.77 & 14.7 & 69.0 & 52 & 37 & 89 & 20.5 & 68.0 & 23 & 2 & 25 & 37.5 & 19.5 & 57 \\
\hline 78 & 75.03 & 7.80 & 6.99 & 10.18 & 17.7 & 64.7 & 7 & 6 & 13 & 22.8 & 70.0 & 41 & 31 & 72 & 24 & 18.5 & 42.5 \\
\hline 79 & 79.00 & 7.54 & 6.28 & 7.18 & 18.5 & 70.5 & 17 & 6 & 23 & 25.6 & 71.4 & 28 & 25 & 53 & 22.5 & 15.5 & 38 \\
\hline 80 & 83.00 & 5.67 & 4.00 & 7.33 & 20.8 & 70.0 & 66 & 60 & 126 & 24.0 & 72.8 & 88 & 46 & 134 & 77 & 53 & 130 \\
\hline 81 & 5.21 & 82.12 & 2.00 & 10.67 & 21.0 & 61.0 & 21 & 9 & 30 & 20.0 & 70.0 & 18 & 12 & 30 & 19.5 & 10.5 & 30 \\
\hline 82 & 20.09 & 70.10 & 3.65 & 6.16 & 22.0 & 73.2 & 33 & 12 & 45 & 21.9 & 65.2 & 24 & 10 & 34 & 28.5 & 11 & 39.5 \\
\hline 83 & 45.67 & 40.87 & 4.01 & 9.45 & 19.0 & 65.0 & 9 & 13 & 22 & 25.5 & 73.6 & 26 & 24 & 50 & 17.5 & 18.5 & 36 \\
\hline 84 & 38.87 & 53.00 & 3.01 & 5.12 & 22.3 & 76.8 & 54 & 40 & 94 & 23.0 & 77.0 & 30 & 23 & 53 & 42 & 31.5 & 73.5 \\
\hline 85 & 59.91 & 18.97 & 7.98 & 13.14 & 16.5 & 80.0 & 41 & 14 & 55 & 19.0 & 78.9 & 52 & 78 & 130 & 46.5 & 46 & 92.5 \\
\hline 86 & 75.67 & 10.00 & 6.22 & 8.11 & 17.9 & 62.3 & 11 & 7 & 18 & 23.0 & 72.3 & 61 & 50 & 111 & 36 & 28.5 & 64.5 \\
\hline 87 & 67.99 & 7.00 & 8.88 & 16.13 & 15.4 & 62.2 & 19 & 6 & 25 & 21.2 & 70.4 & 54 & 55 & 109 & 36.5 & 30.5 & 67 \\
\hline 88 & 69.11 & 6.18 & 18.90 & 5.81 & 14.1 & 77.8 & 34 & 15 & 49 & 19.0 & 80.5 & 41 & 19 & 60 & 37.5 & 17 & 54.5 \\
\hline 89 & 15.43 & 2.33 & 58.95 & 23.29 & 19.6 & 59.0 & 29 & 14 & 43 & 24.0 & 70.0 & 44 & 30 & 74 & 36.5 & 22 & 58.5 \\
\hline 90 & 21.09 & 61.01 & 5.00 & 12.90 & 21.0 & 70.0 & 48 & 54 & 102 & 23.0 & 67.0 & 10 & 1 & 11 & 29 & 27.5 & 56.5 \\
\hline 91 & 40.99 & 48.15 & 4.87 & 5.99 & 19.0 & 66.6 & 61 & 55 & 116 & 21.0 & 79.0 & 12 & 30 & 42 & 36.5 & 42.5 & 79 \\
\hline 92 & 49.23 & 37.11 & 3.69 & 9.97 & 17.5 & 70.2 & 38 & 30 & 68 & 17.8 & 74.2 & 58 & 47 & 105 & 48 & 38.5 & 86.5 \\
\hline 93 & 67.12 & 15.27 & 7.21 & 10.40 & 16.0 & 79.5 & 20 & 10 & 30 & - & - & - & - & 0 & 20 & 10 & 15 \\
\hline 94 & 65.00 & 6.88 & 10.00 & 18.12 & 14.2 & 77.8 & 32 & 24 & 56 & 19.5 & 77.0 & 29 & 27 & 56 & 30.5 & 25.5 & 56 \\
\hline 95 & 18.99 & 1.19 & 38.00 & 41.82 & 13.3 & 77.1 & 46 & 33 & 79 & 23.1 & 70.9 & 58 & 40 & 98 & 52 & 36.5 & 88.5 \\
\hline 96 & 8.09 & 1.27 & 70.07 & 20.57 & 15.1 & 80.5 & 18 & 20 & 38 & 22.0 & 65.3 & 36 & 22 & 58 & 27 & 21 & 48 \\
\hline 97 & 65.00 & 18.45 & 4.00 & 12.55 & 16.0 & 80.1 & 9 & 7 & 16 & 19.6 & 62.1 & 20 & 14 & 34 & 14.5 & 10.5 & 25 \\
\hline 98 & 78.99 & 11.35 & 2.54 & 7.12 & 13.0 & 73.0 & 14 & 10 & 24 & 22.0 & 70.0 & 16 & 19 & 35 & 15 & 14.5 & 29.5 \\
\hline 99 & 18.98 & 70.00 & 3.10 & 7.92 & 11.9 & 79.5 & 14 & 20 & 34 & 18.8 & 69.3 & 28 & 6 & 34 & 21 & 13 & 34 \\
\hline 100 & 45.05 & 37.09 & 8.14 & 9.72 & 17.0 & 77.7 & 40 & 29 & 69 & 22.8 & 66.8 & 88 & 63 & 151 & 64 & 46 & 110 \\
\hline 101 & 57.21 & 30.12 & 6.00 & 6.67 & 16.7 & 73.6 & 34 & 16 & 50 & 23.9 & 75.5 & 82 & 50 & 132 & 58 & 33 & 91 \\
\hline $\begin{array}{l}\text { South Podlasie } \\
\text { Lowland }\end{array}$ & 71.96 & 14.33 & 4.74 & 9.06 & 15.4 & 75.5 & 84.5 & 56 & 140.5 & 19.7 & 70.5 & 92 & 62 & 154 & 88 & 59 & 147.5 \\
\hline Wester Polesie & 56.19 & 29.17 & 6.39 & 7.97 & 13.6 & 77.7 & 86 & 56 & 141.5 & 20.7 & 69.0 & 91 & 59 & 150 & 89 & 57 & 146 \\
\hline Lublin Upland & 61.74 & 24.75 & 3.80 & 9.68 & 15.9 & 72.1 & 35 & 25 & 60 & 19.6 & 69.9 & 32 & 25 & 58 & 32 & 25 & 59 \\
\hline Volyn & 57.12 & 15.76 & 14.54 & 12.57 & 15.4 & 72.6 & 38 & 28 & 66 & 20.4 & 74.5 & 38 & 28 & 66 & 38 & 28 & 66 \\
\hline
\end{tabular}

F-females, M-males, T-temperature, $\mathrm{H}$-humidity. 


\section{References}

1. Földvári, G.; Široký, P.; Szekeres, S.; Majoros, G.; Sprong, H. Dermacentor reticulatus: A vector on the rise. Parasit. Vectors 2016, 9, 314. [CrossRef] [PubMed]

2. Karbowiak, G. The occurrence of the Dermacentor reticulatus tick-Its expansion to new areas and possible causes. Ann. Parasitol. 2014, 60, 37-47. [PubMed]

3. Rubel, F.; Brugger, K.; Pfeffer, M.; Chitimia-Dobler, L.; Didyk, Y.M.; Leverenz, S.; Dautel, H.; Kahl, O. Geographical distribution of Dermacentor marginatus and Dermacentor reticulatus in Europe. Ticks Tick Borne Dis. 2016, 7, 224-233. [CrossRef] [PubMed]

4. Bonnet, S.; De la Fuente, J.; Nicollet, P.; Liu, X.; Madani, N.; Blanchard, B.; Maingourd, C.; Alongi, A.; Torina, A.; Fernández de Mera, I.G.; et al. Prevalence of tick-borne pathogens in adult Dermacentor spp. ticks from nine collection sites in France. Vector Borne Zoonotic Dis. 2013, 13, 226-236. [CrossRef] [PubMed]

5. Jongejan, F.; Ringenier, M.; Putting, M.; Berger, L.; Burgers, S.; Kortekaas, R.; Lenssen, J.; Van Roessel, M.; Wijnveld, M.; Madder, M. Novel foci of Dermacentor reticulatus ticks infected with Babesia canis and Babesia caballi in the Netherlands and in Belgium. Parasit Vectors 2015, 8, 232. [CrossRef] [PubMed]

6. Dautel, H.; Dippel, C.; Oehme, R.; Hartelt, K.; Schettler, E. Evidence for an increased geographical distribution of Dermacentor reticulatus in Germany and detection of Rickettsia sp. RpA4. Int. J. Med. Microbiol. 2006, 40, 149-156. [CrossRef]

7. Duscher, G.G.; Hodžić, A.; Weiler, M.; Vaux, A.G.; Rudolf, I.; Sixl, W.; Medlock, J.M.; Versteirt, V.; Hubálek, Z. First report of Rickettsia raoultii in field collected Dermacentor reticulatus ticks from Austria. Ticks Tick Borne Dis. 2016, 7, 720-722. [CrossRef]

8. Špitalská, E.; Štefanidesová, K.; Kocianová, E.; Boldiš, V. Rickettsia slovaca and Rickettsia raoultii in Dermacentor marginatus and Dermacentor reticulatus ticks from Slovak Republic. Exp. App. Acarol. 2012, 57, 189-197. [CrossRef]

9. Sreter, T.; Szell, Z.; Varga, I. Spatial distribution of Dermacentor reticulatus and Ixodes ricinus in Hungary: Evidence for change? Vet. Parasitol. 2005, 128, 347-351. [CrossRef]

10. Olsuf'ev, N.G. On ecology of the meadow tick Dermacentor pictus Herm, origin of its foci, and ways of eradicating it in the middle of the European part of RSFSR. Problems Reg. Gen. Exp. Parasitol. Med. Zool. Mosc. 1953, 8, 49-98. (In Russian)

11. Paulauskas, A.; Radzijevskaja, J.; Turčinavičienė, J.; Ambrasienè, D.; Galdikaitė, E. Data on some Ixodid tick species (Acari, Ixodidae) in the Baltic countries. New Rare Lith. Insects Species 2010, 22, 43-51.

12. Razumova, I. The activity of Dermacentor reticulatus Fabr. (Ixodidae) ticks in nature. Med. Parazitol. 1998, 4 , 8-14. (In Russian)

13. Szymański, S. Distribution of the tick Dermacentor reticulatus (Fabricus, 1794)(Ixodidae) in Poland. Acta Parasitol. 1986, 31, 143-154.

14. Lachmajer, J. The state of research on Arthropoda parasites in Poland. Ann. Parasitol. 1963, 9, 4. (In Polish)

15. Siuda, K. Ticks (Acari: Ixodida) of Poland. Part II Taxonomy and Distribution; Polish Parasitological Society Press: Warsaw, Poland, 1993. (In Polish)

16. Kadulski, S.; Izdebska, J.N. New data on distribution of Dermacentor reticulatus (Fabr.) (Acari, Ixodidae) in Poland. In Arthropods and Their Invasions; Buczek, A., Błaszak, C., Eds.; Akapit: Lublin, Poland, 2009; pp. 53-58.

17. Kiewra, D.; Czułowska, A. Evidence for an increased distribution range of Dermacentor reticulatus in south-west Poland. Exp. App. Acarol. 2013, 59, 501-506. [CrossRef] [PubMed]

18. Król, N.; Kiewra, D.; Lonc, E.; Janaczyk, B.; Chodorowska-Skubiszewska, A.; Dzięcioł, M.; Gola, M.; Gruszka, R.; Jackowska-Szlachcic, E. Dermacentor reticulatus (Fabricius, 1794) and Babesia canis (Piana et Galli-Valerio, 1895) as the parasites of companion animals (dogs and cats) in the Wroclaw area, south-western Poland. Ann. Parasitol. 2016, 62, 125-130.

19. Kubiak, K.; Sielaw, H.; Dziekońska-Rynko, J.; Kubiak, D.; Rydzewska, M.; Dzika, E. Dermacentor reticulatus ticks (Acari: Ixodidae) distribution in north-eastern Poland: An endemic area of tick-borne diseases. Exp. App. Acarol. 2018, 75, 289-298. [CrossRef]

20. Mierzejewska, E.J.; Estrada-Peña, A.; Alsarraf, M.; Kowalec, M.; Bajer, A. Mapping of Dermacentor reticulatus expansion in Poland in 2012-2014. Ticks Tick Borne Dis. 2016, 7, 94-106. [CrossRef] 
21. Nowak, M. Discovery of Dermacentor reticulatus (Acari: Amblyommidae) populations in the Lubuskie Province (Western Poland). Exp. App. Acarol. 2011, 54, 191-197. [CrossRef]

22. Opalińska, P.; Wierzbicka, A.; Asman, M. The PCR and nested PCR detection of Borrelia burgdorferi sensu lato, Anaplasma phagocytophilum and Babesia microti in Dermacentor reticulatus F. collected in a new location in Poland (Trzciel, Western Poland). Acta. Parasitol. 2016, 61, 849-854. [CrossRef]

23. Immler, R.M. Studies on the biology and ecology of Dermacentor reticulatus tick (Fabricius, 1794) (Ixodidae) in an endemic area. Mitt. Schweiz. Entomol. Ges. 1973, 46, 2-70. (In German)

24. Bullová, E.; Lukáň, M.; Stanko, M.; Pet'ko, B. Spatial distribution of Dermacentor reticulatus tick in Slovakia in the beginning of the 21st century. Vet. Parasitol. 2009, 165, 357-360. [CrossRef] [PubMed]

25. Široký, P.; Kubelová, M.; Bednář, M.; Modrý, D.; Hubálek, Z.; Tkadlec, E. The distribution and spreading pattern of Dermacentor reticulatus over its threshold area in the Czech Republic-How much is range of this vector expanding? Vet. Parasitol. 2011, 183, 130-135.

26. Földvári, G.; Farkas, R. Ixodid tick species attaching to dogs in Hungary. Vet. Parasitol. 2005, 129, $125-131$. [CrossRef]

27. Hornok, S.; Farkas, R. Influence of biotope on the distribution and peak activity of questing ixodid ticks in Hungary. Med. Vet. Entomol. 2009, 23, 41-46. [CrossRef]

28. Széll, Z.; Sréter-Lancz, Z.; Márialigeti, K.; Sréter, T. Temporal distribution of Ixodes ricinus, Dermacentor reticulatus and Haemaphysalis concinna in Hungary. Vet. Parasitol. 2006, 141, 377-379. [CrossRef]

29. Coipan, E.C.; Vladimirescu, A.F.; Ciolpan, O.; Teodorescu, I. Tick species (Acari: Ixodoidea) distribution, seasonality and host associations in Romania. Trav. Mus. Natl. d'Histoire Nat. Grigore Antipa 2011, 54, 301-317. [CrossRef]

30. Chitimia-Dobler, L. Spatial distribution of Dermacentor reticulatus in Romania. Vet. Parasitol. 2015, 214, 219-223. [CrossRef]

31. Krčmar, S.; Vereš, M.; Trliar, T. Fauna of hard ticks (Acari: Ixodidae) in different habitats in Croatian part of Baranja. Šumarski. List 2014, 5-6, 309-314.

32. Mihaljica, D.; Radulović, Z.; Tomanović, S.; Cakić, S.; Penezić, A.; Milutinović, M. Molecular detection of Babesia spp. in ticks in northern Serbia. Arch. Biol. Sci. Belgrade 2012, 64, 591-598. [CrossRef]

33. Omeragic, J. Ixodid ticks in Bosnia and Herzegovina. Exp. Appl. Acarol. 2011, 53, 301-309. [CrossRef] [PubMed]

34. Tomanović, S.; Chochlakis, D.; Radulović, Ž.; Milutinović, M.; Ćakić, S.; Mihaljica, D.; Tselentis, Y.; Psaroulaki, A. Analysis of pathogen co-occurrence in host-seeking adult hard ticks from Serbia. Exp. App. Acarol. 2013, 59, 367-376. [CrossRef] [PubMed]

35. Garcia-Sanmartin, J.; Barandika, J.F.; Juste, R.A.; Garcia-Perez, A.L.; Hurtado, A. Distribution and molecular detection of Theileria and Babesia in questing ticks from northern Spain. Med. Vet. Entomol. 2008, 22, 318-325. [CrossRef] [PubMed]

36. Olivieri, E.; Zanzani, S.A.; Latrofa, M.S.; Lia, R.P.; Dantas-Torres, F.; Otranto, D.; Manfredi, M.T. The southernmost foci of Dermacentor reticulatus in Italy and associated Babesia canis infection in dogs. Parasit. Vectors 2016, 9, 213. [CrossRef]

37. Kloch, A.; Mierzejewska, E.J.; Karbowiak, G.; Slivinska, K.; Alsarraf, M.; Rodo, A.; Kowalec, M.; Dwuznik, D.; Didyk, Y.M.; Bajer, A. Origins of recently emerged foci of the tick Dermacentor reticulatus in Central Europe inferred from molecular markers. Vet. Parasitol. 2017, 237, 63-69. [CrossRef]

38. Radwan, S. Polesie National Park. Monography; Morpol Press: Lublin, Poland, 2002. (In Polish)

39. Available online: https://commons.wikimedia.org/wiki/File:Europe_topography_map.png (accessed on 15 November 2019).

40. Available online: https://commons.wikimedia.org/wiki/File:Poland-hipsometric_map.jpg (accessed on 15 November 2019).

41. Kondracki, J. Regional Geography of Poland; PWN Press: Warsaw, Poland, 2000.

42. Available online: https://pl.wikipedia.org/wiki/Plik:Lubelskie_mapa_fizyczna.png (accessed on 15 November 2019).

43. Zając, Z.; Bartosik, K.; Buczek, A. Factors influencing the distribution and activity of Dermacentor reticulatus (F.) ticks in an anthropopressure-unaffected area in central-eastern Poland. Ann. Agric. Environ. Med. 2016, 23, 270-275. [CrossRef] 
44. Nowak-Chmura, M. Ticks (Ixodida) of Central Europe; Pedagogical University of Cracow Press: Cracow, Poland, 2013. (In Polish)

45. Bartosik, K.; Wiśniowski, L.; Buczek, A. Abundance and seasonal activity of adult Dermacentor reticulatus (Acari: Amblyommidae) in eastern Poland in relation to meteorological conditions and the photoperiod. Ann. Agric. Environ. Med. 2011, 18, 340-344.

46. Buczek, A.; Bartosik, K.; Wiśniowski, Ł.; Tomasiewicz, K. Changes in population abundance of adult Dermacentor reticulatus (Acari: Amblyommidae) in long-term investigations in eastern Poland. Ann. Agric. Environ. Med. 2013, 20, 269-272.

47. Estrada-Peña, A.; Mihalca, A.D.; Petney, T.N. Ticks of Europe and North Africa: A Guide to Species Identification; Springer: Berlin/Heidelberg, Germany, 2009; pp. 287-292.

48. Available online: https:/www.google.com/maps/place/lubelskie/@51.2644085,21.7604799,269835m/ data=!3m2!1e3!4b1!4m5!3m4!1s0x4723ad1204d54b2b:0x1017cadc5e4c040!8m2!3d51.2493519!4d23.1011392 (accessed on 15 November 2019).

49. Sonenshine, D.E. Pheromones and other semiochemicals of ticks and their use in tick control. Parasitology 2004, 129, 405-425. [CrossRef]

50. Bartosik, K.; Wiśniowski, Ł.; Buczek, A. Questing behavior of Dermacentor reticulatus adults (Acari: Amblyommidae) during diurnal activity periods in eastern Poland. J. Med. Entomol. 2012, 49, 859-864. [CrossRef]

51. Buczek, A.; Zając, Z.; Woźniak, A.; Kulina, D.; Bartosik, K. Locomotor activity of adult Dermacentor reticulatus ticks (Ixodida: Ixodidae) in natural conditions. Ann. Agric. Environ. Med. 2017, 24, 271-275. [CrossRef]

52. Mierzejewska, E.J.; Estrada-Peña, A.; Bajer, A. Spread of Dermacentor reticulatus is associated with the loss of forest area. Exp. App. Acarol. 2017, 72, 399-413. [CrossRef] [PubMed]

53. Martinod, S.; Gilot, B. Epidemiology of canine babesiosis in relation to the activity of Dermacentor reticulatus in southern Jura (France). Exp. App. Acarol. 1991, 11, 215-222. [CrossRef]

54. Bogdaszewska, Z. Range and ecology of Dermacentor reticulatus (Fabricius, 1794) in Mazuria focus. II. Seasonal activity patterns of the adults. Ann. Parasitol. 2004, 4, 731-738.

55. Cios, H. Risk Assessment for Ixodes Ricinus Tick Attacks in Various Climatic Regions of the Lublin Region. Ph.D. Thesis, Medical University of Lublin, Lublin, Poland, 2014. (In Polish).

56. Migdał, W.; Zając, M.; Rutkowska-Mazur, A.; Migdał, Ł. Wild boar-ASF threat and meat management. Prz. Hod. 2018, 4, 1-5. (In Polish)

57. Fryderyk, S. A new interesting finding of Dermacentor reticulatus (Fabr.) (Acari: Ixodida: Ixodidae) on the wild boar (Sus scrofa L.). Ann. Parasitol. 1998, 44, 737-739. (In Polish)

58. Ortuno, A.; Quesada, M.; Lopez-Claessens, S.; Castella, J.; Sanfeliu, I.; Anton, E.; Segura-Porta, F. The role of wild boar (Sus scrofa) in the eco-epidemiology of R. slovaca in northeastern Spain. Vector Borne Zoonotic Dis. 2007, 7, 59-64. [CrossRef] [PubMed]

59. Zając, V.; Wójcik-Fatla, A.; Sawczyn, A.; Cisak, E.; Sroka, J.; Kloc, A.; Zajac, Z.; Buczek, A.; Dutkiewicz, J.; Bartosik, K. Prevalence of infections and co-infections with 6 pathogens in Dermacentor reticulatus ticks collected in eastern Poland. Ann. Agric. Environ. Med. 2017, 24, 26-32. [CrossRef]

60. Ličková, M.; Havlíková, S.F.; Sláviková, M.; Slovák, M.; Drexler, J.F.; Klempa, B. Dermacentor reticulatus is a vector of tick-borne encephalitis virus. Ticks Tick Borne Dis. 2020. in Press.

61. Daniels, T.J.; Boccia, T.M.; Varde, S.; Marcus, J.; Le, J.; Bucher, D.J.; Falco, R.C.; Schwartz, I. Geographic risk for Lyme disease and human granulocytic ehrlichiosis in southern New York State. Appl. Environ. Microbiol. 1998, 64, 4663-4669. [CrossRef]

62. Adaszek, Ł.; Kalinowski, M.; Kutrzuba, J.; Ziętek, J.; Winiarczyk, S. Difficulties in diagnosing of Lyme disease in dogs. Życie Wet. 2010, 85, 414-417. (In Polish)

63. Adaszek, Ł.; Winiarczyk, S.; Puchalski, A.; Garbal, M.; Górna, M. The diagnose of Borrelia afzelii infections in dogs. Ann. Univ. Mariae Curie Skłodowska. Sect. DD Med. Vet. 2009, 64, 15-21. [CrossRef]

64. Winiarczyk, S.; Adaszek, L.; Stefancikova, A.; Pet'ko, B.; Cislakova, L.; Puchalski, A. Serological tests for Lyme disease and erlichiosis of pigs and cows in the Lublin region. Med. Vet. 2007, 63, 561-565.

(C) 2020 by the authors. Licensee MDPI, Basel, Switzerland. This article is an open access article distributed under the terms and conditions of the Creative Commons Attribution (CC BY) license (http://creativecommons.org/licenses/by/4.0/). 